\title{
THE EUROPEAN COMPETITION NETWORK AND THE SHAPING OF EU COMPETITION POLICY
}

\begin{abstract}
Mislav Mataija*
Summary: This paper assesses the functioning of the European Competition Network (ECN) introduced by the EC's modernisation package of 2004 to replace the European Commission's enforcement monopoly in the field of competition law. By all accounts, and contrary to the fears of early critics, the modernisation of EC competition policy and the decentralisation of its enforcement have not led to disintegration within the network of competition regulators. The institutional differences between national competition authorities (NCAs) have so far not had a negative impact. The ECN is fuelled by the nature of the increasingly technocratic and expert-driven discipline of competition law, as well as by the Commission's conscious strategy of 'soft' centralisation. The new system is also reinforcing a specific perspective on competition law, focused on market efficiency, and viewed as an autonomous discipline divorced from outside pressures and influence by the Member States. Even though such a conclusion seems counterintuitive, overall the ECN has had, and is likely to have, a unifying effect both in enforcement and in policy formation. There are, however, pressures in the opposite direction, which might become stronger as the NCAs' experience grows and horizontal communication increases in frequency.
\end{abstract}

\section{The European Competition Network - central issues}

Competition has long been regarded as one of the most important and centralised areas of European Community policy. Competition rules, most prominently today's arts 101 and 102 of the Treaty on the Functioning of the European Union, have given EU institutions a clear enforcement mandate. To be sure, there has been plenty of disagreement on what purpose the rules should serve, and ideas on the proper role of competition policy have changed dramatically over time. ${ }^{1}$ Nevertheless, competition policy continues to hold a position of prominence among Community activities.

\footnotetext{
PhD researcher, European University Institute. The author wishes to thank Professor Charles Sabel of Columbia Law School and Professor Yane Svetiev of Brooklyn Law School for their comments and guidance.

1 See eg David J Gerber, Global Competition: Law, Markets, and Globalization (OUP, Oxford 2010) 183-202.
} 
Thus, it is easy to see why so much academic and professional attention has been devoted to the modernisation of EC competition policy, formally taking place in 2004 with the coming into force of Regulation $1 / 2003,{ }^{2}$ described by a leading competition law expert as a 'cultural and legal revolution'. ${ }^{3}$ This paper will focus on a key element of that reform the formation of the European Competition Network (ECN), consisting of the European Commission as Europe's leading competition enforcer, and the Member States' national competition authorities (NCAs). ${ }^{4}$ In particular, the aim will be to assess the network's effectiveness and its possible influence on the development of competition policy in the EU and the Member States, as well as to address some challenges posed by informal, not fully transparent network-style regulation. The paper is limited to the areas covered by Regulation 1/2003, ie to antitrust issues falling under arts 101 and 102 TFEU. The impact of modernisation on mergers and state aid regulation is not addressed, ${ }^{5}$ except tangentially.

As a whole, modernisation introduced two sweeping changes. The first one is a new system of enforcement, in which companies no longer have to pre-emptively notify their agreements for review by the Commission, but will be subject to legal action only ex officio or upon complaint. The second is the formal decentralisation of enforcement, from the Commission to the NCAs. This seemingly curious case of an agent (the Commission) ceding the enforcement monopoly granted to it by the principals (the Member States) back to the Member States' own regulatory entities has captured the attention of several political scientists. ${ }^{6}$

The ECN's basic purpose is to facilitate the enforcement of Community competition law. As Regulation 1/2003 provides, the NCAs become primary enforcers of EC competition rules, alongside the Commission. Either the Commission or any NCA can begin an investigation into an alleged breach of EC competition rules. Without ironclad rules on the

\footnotetext{
2 Council Regulation (EC) $1 / 2003$ of 16 December 2002 on the implementation of the rules on competition laid down in Articles 81 and 82 of the Treaty [2003] OJ L1.

3 Claus Dieter Ehlermann, 'The Modernization of EC Antitrust Policy: A Legal and Cultural Revolution' (2000) 37 CML Rev 537.

4 Some NCAs have not joined the Network. An example is the UK Competition Commission (the UK is represented in the ECN by the Office of Fair Trading, with which it shares competence in this area).

$5 \quad$ For an account of merger regulation, see Lee McGowan \& Michele Cini, 'Discretion and Politicization in EU Competition Policy: The Case of Merger Control' (1999) 12 Governance 175.

6 See Stephen Wilks, 'Agency Escape: Decentralization or Dominance of the European Commission in the Modernization of Competition Policy?' (2005) 18 Governance 431; Giandomenico Majone, 'Two Logics of Delegation: Agency and Fiduciary Relations in EC' (2001) 2 (1) European Union Politics 103; Dirk Lehmkuhl, 'On Government, Governance and Judicial Review: The Case of European Competition Policy' (2008) 28 Journal of Public Policy 139; Adrienne Héritier \& Dirk Lehmkuhl, 'Introduction: The Shadow of Hierarchy and New Modes of Governance' (2008) 28 Journal of Public Policy 1.
} 
division of jurisdiction or policy competence, the ECN becomes necessary as a co-ordination mechanism in a system of dispersed regulatory authority.

The rules of co-ordination and co-operation, insofar as they are formalised at all, are contained in a Commission Notice, ${ }^{7}$ a non-binding instrument accepted voluntarily by the Member States. Nevertheless, the ECN does not fit the mould of a classic informal network, in which the relationships between actors develop organically through time-honoured practices. ${ }^{8}$ Rather, there are explicit rules reserving authority for the Commission, which not only has to be notified of all individual cases but can 'pluck' any case from an NCA, at discretion. Thus, it has been argued that the ECN is not a typical, but a 'managed' network, in which the relationship between the 'nodes' (NCAs) is not nearly as robust as the communication with the 'central node' (the Commission). ${ }^{9}$

This feature of the network can help to explain why, so far at least, it has not watered down Community competition policy. If anything, it has strengthened both enforcement and policy focus. There have been no recorded cases of jurisdictional conflicts or other serious disagreements between the NCAs in dispensing their enforcement powers. Of course, as will be discussed below, the information we have is limited, but so far there is no reason to disagree with the Commission's finding that:

Work sharing between the enforcers in the network has generally been unproblematic. Five years of experience have confirmed that the flexible and pragmatic arrangements introduced by Regulation 1/2003 and the Network Notice work well. Discussions on caseallocation have come up in very few cases and have been resolved swiftly. ${ }^{10}$

The Commission has not yet used its strongest weapon - removal, ie taking over a case initiated by an NCA. Despite a number of centrifugal tendencies, the network so far seems remarkably coherent and effective (which is not to say things cannot change).

\footnotetext{
7 Commission Notice (EC) on cooperation within the Network of Competition Authorities [2004] OJ C101.

8 Firat Cengiz, 'The European Competition Network: Structure, Management and Initial Experiences of Policy Enforcement' (2009) EUI Max Weber Programme Working Paper MWP 2009/5, 5-6. See also Cengiz (n 46) 14 ff, contrasting the features of the ECN with the features expected by network theory (eg central planning vs voluntary formation, lack of dispute resolution mechanisms vs strong dispute resolution mechanisms, hierarchy vs equal positions of members).

9 Cengiz, 'European Competition Network' (n 8) 10. See also Stephen Wilks, 'Agencies, Networks, Discourses and the Trajectory of European Competition Enforcement' (2007) 3 European Competition Journal 437, 448.

10 Commission (EC) 'Report on Competition Policy 2007' COM (2008) 368 final, 16 June 2008, 7.
} 
Co-operation within the ECN is not, however, exhausted by enforcement, ie the application of a body of rules to individual cases. It is also a policy-planning network, even though its role in that respect is not fully transparent. The Commission is using the network as a platform for the development of a 'common competition culture'. ${ }^{11}$ The NCAs are relying on it as an opportunity for their position to be heard and perhaps included in the formulation of Community policy. ${ }^{12}$ For some of the less experienced NCAs, it is presumably a forum for learning. ${ }^{13}$

The network is not, however, developing policy from scratch or renegotiating its values in light of the NCAs' inputs. Their supposed differences have not been reflected in the development of Community policy so far. Rather, it will be argued in this paper that the ECN is so far being used to further a specific vision of competition policy, emanating primarily from the Commission.

In the remaining sections of this paper, I will describe the functioning of the network, drawing on legal documents such as Regulation 1/2003, the Commission's soft law documents, as well as on annual reports of several NCAs. ${ }^{14}$ I will attempt to advance the claim that the ECN is much more efficient, centralised, and less subject to pressures of divergence than a typical regulatory network, thanks in part to rules granting the Commission a centralising role, but also to the specific nature of competition law and policy, which fosters a highly technical, specialist discourse among experts, leading to the formation of an 'epistemic community'.

I will also address the role of the network in the planning and shaping of policy, arguing first that the network has already gone far in this regard, and, second, that in the near future the majority of the NCAs are likely to rally behind a specific vision of competition, rather than enrich or complicate the policy debate. It will also be argued that there are two significant problems in using the ECN as a platform of policy development and dissemination: lack of transparency and lack of democratic accountability.

\footnotetext{
11 Commission Notice (n 7) para 1.

12 Wilks (n 9) 449.

13 For an example of such a perspective, see, eg, the press release 'The Agency is Fit for EU' issued by the Croatian Competition Agency in June 2009, describing the Agency's cooperation with their Austrian counterpart, the Bundeswettbewerbsbehörde: '... the Austrian competition experts are more than willing to support their Croatian counterparts in competition advocacy, which effectively conducted, contributes to the establishment of what is referred to as a "competition culture"' <http://www.aztn.hr/article/233/quotagencija-je-spremnaza-euquot> accessed on 8 December 2010.

14 Given the lack of information on the ECN, the best, albeit incomplete and anecdotal, source on the discussions and procedures within the network are the reports issued by the NCAs and the Commission. The NCAs' reports were chosen based on the level of detail with which their reports discuss the ECN and other forms of European co-operation. The reports used here are those of the German, French (Conseil de la Concurrence), Dutch, Czech, Romanian and Polish NCAs.
} 


\subsection{Theoretical puzzles}

One of the reasons why the ECN has drawn considerable scholarly attention is the fact that it has so far functioned effectively, with no noticeable rifts in policy or significant administrative deficiencies. In a nutshell, the ECN seems rather tightly integrated and committed to the pursuit of common policies. This stands in contrast to research on regulatory networks ${ }^{15}$ which shows the difficulty of co-ordinating diverse interests and values in a decentralised setting with flexible rules of co-operation. Competition policy does not seem to be a likely exception to those conclusions $^{16}$ - so how can the network's effectiveness be explained?

First of all, the ECN does not neatly fit the description of such networ$\mathrm{ks}$ because of its structural centralising features, ie the significant degree of control given to the Commission. ${ }^{17}$ The very fact that co-operation is formalised through legal rules seems at odds with the network concept in which 'management controls... emerge naturally as the networks continue to function...', reflecting 'routinized courses of conduct achieved through past cooperation experiences'. ${ }^{18}$ Formal rules of co-operation can thus prevent decentralisation. As I will argue, this partly solves the puzzle, but not completely.

Another puzzle is that of an agent ceding hard-earned authority. Is the Commission truly giving away its monopoly in competition enforcement? It has been argued that the Commission itself is not a good example of an agent because it has outgrown that role; Majone describes it as a 'trustee' of competition policy. ${ }^{19}$ The Commission's ability to go beyond its original mandate can also be at least partly explained by the lack of agreement among the more powerful Member States on how exactly to enforce their visions of competition, with the result that:

...the influence of the shadow of hierarchy by territorially bound democratic government on the efficiency of sectoral governance was quite limited. In turn, it was the Commission's strategy to increase the efficiency of its policies by resorting to new modes of governance that bypassed both the member states and the European Parliament. ${ }^{20}$

A different question is how well the move towards decentralisation fits into a neofunctionalist framework which has been used to explain

15 David Coen \& Mark Thatcher, 'Network Governance and Multi-level Delegation: European Networks of Regulatory Agencies' (2008) 28 Journal of Public Policy 49, 56-59.

16 Wilks (n 9).

17 Cengiz, 'European Competition Network' (n 8) 8.

18 Cengiz, 'European Competition Network' (n 8) 9.

19 Majone (n 6) 104-105.

20 Lehmkuhl (n 6) 149. 
the gradual centralisation of competition enforcement in the hands of the European Commission's DG Comp (see below in 3.1). Is this a step back, contrary to neofunctionalist expectations? ${ }^{21}$ Or can it be explained away by viewing the NCAs as part and parcel of the Commission's functionally organised structure, while national political preferences play a larger role in the Council? ${ }^{22}$

These and other problems show that the specific case of the ECN, and more generally of competition law, is (unsurprisingly) difficult to frame within a single theory. This paper will not try to provide definitive answers to theoretical questions as applied to competition enforcement, but will make use of the mentioned concepts insofar as they can help illustrate some of the issues raised.

\subsection{Co-ordination in international antitrust}

Before delving into the actual system of co-operation within the ECN, it is worth explaining briefly why competition policy creates cross-border issues and, arguably, requires transnational regulation or co-operation between regulators.

First of all, it is almost impossible to constrain the consequences of anticompetitive conduct within the borders of a single regulatory regime. ${ }^{23}$ Even if the restraint took place in one state, it can have effects in another, whether explicitly (eg a price-fixing export cartel) or collaterally (eg a dumped price can affect all markets where a good is sold). Some potentially anticompetitive conduct directly affects international trade, such as a vertical restraint (eg an exclusive distribution agreement for good A in country X) coupled with the prohibition of so-called parallel imports (good A imported to country X from country $\mathrm{Y}$ to circumvent an exclusive distribution agreement). Some conduct is in itself transnational, such as an agreement between the world's leading suppliers of a certain good to fix prices.

Transnational restraints become more troublesome when you only have national laws and regulators. ${ }^{24}$ Their standards can vary, allowing undertakings to take advantage of lax competition rules of a certain jurisdiction to the detriment of competition elsewhere (especially in cases such as the already mentioned export cartels). There is also the problem of a narrow perspective: even under perfectly reasonable market analysis,

\footnotetext{
${ }_{21}$ Øivind Støle, 'Towards a Multi-Level Community Administration? The Decentralization of EU Competition Policy' (2005) ARENA Working Papers, WP 05/05, 14.

22 Støle (n 21) 18.

23 Eleanor M Fox, 'The Elusive Promise of Modernisation: Europe and the World' (2001) 28 Legal Issues of Economic Integration 141, 146.

24 Eleanor M Fox, 'Antitrust and Regulatory Federalism: Races Up, Down, And Sideways' (2000) 75 New York University Law Review 1781, 1800-1801.
} 
conduct which appears to be competitive locally can be anticompetitive globally, and vice versa. In many states, the rules are themselves (in a sense) extraterritorial, allowing restraints to be challenged whenever they affect the local market, but enforcement is still clearly domestic. Another complication is the fact that evidence may be located in many different countries, beyond the reach of a single regulator. All this, without even getting into all the differences between the regulating institutions themselves: differing incentives, institutional rules, independence, structure, competence, experience, etc. ${ }^{25}$

Similar problems have led to vigorous ongoing discussion on creating a global, multilateral competition agreement within the WTO. ${ }^{26}$ These debates usually crystallise into two approaches to transnational regulation. The first is relatively centralised: common rules, perhaps with common enforcement. The strongest form of this was the EC's regime up to Regulation $1 / 2003$. The second one is relatively decentralised: maintaining the diversity of national laws and enforcement, but adopting some common principles or minimum standards and requiring some co-operation, such as mutual assistance in investigations. ${ }^{27}$ The EC's modernised regime introduces some elements of the second solution. However, as I will argue, it would be wrong to think that what happened was, at its core, decentralisation.

\section{A closer look at the modernised system}

\subsection{The nuts and bolts: Regulation $1 / 2003$}

The modernised system contains a number of provisions on the cooperation of the Commission and the NCAs, which are at once robust and flexible. The Regulation, which applies to restrictive agreements and unilateral conduct under arts 101 and 102 TFEU, empowers the NCAs to apply EU competition rules in individual cases, decide that infringements be brought to an end, order interim measures, accept commitments and impose fines and penalties. ${ }^{28}$ It also contains a number of provisions on

\footnotetext{
25 Petros C Mavroidis and Damien J Neven, 'The White Paper: A Whiter Shade of Pale - Of Interest and Interests' (2000) EUI-RSCAS/Competition 2000, 5, 9-10.

26 See eg Fox (n 24) 1786-88.

27 For a more detailed survey of possible approaches, see Roland Weinrauch, Competition Law in the WTO: The Rationale for a Framework Agreement (Neuer Wissenschaftlicher Verlag, Vienna 2004) 111-129.

28 National courts are also authorised to apply those provisions (art 6). An important distinction that has to be kept in mind is that the Regulation deals with the application of EC competition rules, namely arts 81 and 82 EC. National competition laws still exist in the Member States. The details of the complex relationship between national and European competition rules are beyond the scope of this article. See, eg David J Gerber, Law and Competition in Twentieth Century Europe: Protecting Prometheus (OUP, Oxford 2001).
} 
the co-operation of the NCAs with each other and with the Commission, whose enforcement powers are laid out in even more detail. ${ }^{29}$ As a general rule, the Regulation's rules on co-operation with the Commission are mandatory, whereas the rules on co-operation between the NCAs are optional - but, according to the NCAs' annual reports, largely followed.

Thus, an investigating NCA has to inform the Commission without delay, and may also inform the other NCAs, when it commences its first investigative measure. ${ }^{30}$ This option has been taken up by the NCAs, ${ }^{31}$ and is done in practice by posting a notice on the common intranet ${ }^{32}$ or by publishing a so-called 'New Case' form.

In most cases, an NCA also has to notify the Commission 30 days before adopting a decision, ${ }^{33}$ again with the possibility of notifying the other NCAs. Apart from a summary of the case and the text of the proposed decision, the Commission can request all other documents necessary for the assessment of the case. The NCAs are also free to exchange such documents amongst themselves, insofar as they are necessary for the assessment of an individual case. They have the power to provide one another with and use in evidence any matter of fact or of law, including confidential information. ${ }^{34}$ The NCAs' reports indicate that this option is exercised. ${ }^{35}$

There is also a more general provision allowing the NCAs to consult the Commission on any case dealt with under Community law. ${ }^{36}$ This seems to extend to anything - facts, evidence, and even guidance on the proper legal or economic interpretation - that an NCA might be curious about when dealing with a specific case. The Commission, for its part, is bound to transmit to the NCAs 'copies of the most important documents it has collected with a view to applying' its enforcement powers - a remarkably broad, yet vague, duty (which documents, when and why?).

The NCAs are also bound to assist the Commission in obtaining evidence, most prominently by conducting 'dawn raids' of the premises of companies suspected of wrongdoing. Several NCAs have indicated that

\footnotetext{
29 Arts $7-10$.

30 Art 11 para 3.

31 See Conseil de la Concurrence, 2006 Activity Report 36; Bundeskartellamt, Our Activities in 2003 and 2004 11-12. For a list of links to the NCAs' annual reports, see <http:// ec.europa.eu/competition/ecn/annual_reports.html> (links hereinafter omitted).

32 For example, in 2005 the Czech authority received 209 concentration notifications through the network. Office for the Protection of Competition, Annual Report 2005,31.

33 Art 11 para 4.

34 Art 12.

35 The Dutch NCA has formed a special unit and a 'disclosure officer' for this purpose. See Netherlands Competition Authority, Annual Report 2004 - NMa and DTe 22.

36 Art 11 para 5.
} 
they have done so, ${ }^{37}$ and that they have also assisted the investigations of other NCAs. ${ }^{38}$

How can the Commission control the NCAs' potentially erroneous application of Community law? Apart from the less formal channels of notification and consultation mentioned above, the final step could be art $11 / 6$, which allows the Commission to assume jurisdiction in any individual case. Not only does the initiation of a Commission investigation pre-empt NCAs from acting in the same case, but the Commission can also assume jurisdiction even if an NCA has already acted, as long as it 'consults' the NCA. This power has, however, so far not been applied by the Commission, although the Commission is constantly reviewing the NCAs' investigations informally. ${ }^{39}$

Finally, the European Competition Network as such was established subsequently by the Commission's 'Network Notice'. ${ }^{40}$ The Notice lays down a number of rules on investigative procedures, most notably on the allocation of competences between the NCAs. These will be analysed in the following Section.

\subsection{Allocation of competences in the ECN}

When two NCAs start investigating the same practice, Regulation $1 / 2003$ stipulates that the fact that one of them is already dealing with it suffices for the others, or even the Commission, to suspend proceedings or reject the complaint. ${ }^{41}$ Apart from this, there is no legally binding system for the allocation of competences between the NCAs. One could imagine an almost endless set of jurisdictional criteria: turnover of the firms being investigated, location of evidence, place where a restrictive agreement was concluded, etc. However, the system does not try to do this, maintaining the NCAs' parallel competence.

The Notice implements the possibilities of co-operation sketched by the Regulation, giving them shape and detail, while clarifying the allocation of competences. Some criteria are laid down for the selection of the authority 'well placed' to take over, ${ }^{42}$ but as a general rule, the NCA that

\footnotetext{
37 See Netherlands Competition Authority, NMa Annual Report 2005, 101.

38 In one its reports, for example, the German Bundeskartellamt mentioned that it conducted a search on behalf of the Italian NCA, taking testimony from witnesses, and received similar assistance from the Austrian NCA. In the same period, it assisted the European Commission in ten inspections. See Bundeskartellamt, Our Activities in 2003 and 2004, 14.

39 Commission (EC) 'Report on Competition Policy 2007' COM (2008) 368 final, 16 June 2008, 21.

40 See $\mathrm{n} 7$.

41 Art 13.

${ }^{42}$ Commission Notice (n 7) paras 7-10.
} 
takes hold of the case first has jurisdiction. ${ }^{43}$ Joint investigations are possible in cases where one NCA cannot deal with the case effectively, and the Commission should take over when the markets of more than three Member States are affected. ${ }^{44}$ The Notice requires the NCAs to notify each other of new investigations and share information extensively. ${ }^{45}$

The relative laxity of these rules led some to believe that jurisdictional conflicts would be a big issue in the network. ${ }^{46}$ It seems, however, that this has not been the case. The NCAs do not seem to be trying to pre-empt their peers by starting investigations. Rather, they engage in informal, often multilateral discussions within the network and decide who is best placed to investigate, ${ }^{47}$ and for cases involving several jurisdictions there is always the possibility of reallocation to the Commission. ${ }^{48}$ In addition, the Commission's powers of information, supervision and removal are indeed a strong hedge against the risk of regulatory divergence. ${ }^{49}$

However, the Commission's procedural powers cannot fully explain the close integration within the ECN.

\subsection{Beyond the call of duty - implementing the co-operation rules}

The system of information sharing within the network is succinctly described in an annual report of the Czech NCA:

By means of the ECN Interactive network, the competition authorities and the Commission inform each other about the commencement of cases, their interruption and about requests for the application of the so called Leniency Program. ${ }^{50}$

\footnotetext{
43 Commission Notice (n 7) para 6.

44 Commission Notice (n 7 ) para 14.

45 Commission Notice (n 7) paras 2.2.1 - 2.2.3.

46 See Firat Cengiz, 'Regulation 1/2003 Revisited' (2009) TILEC Discussion Paper DP 2009042, 18-19, and the works cited in footnote 69.

47 For example, the Dutch NCA reports that a case initially subject to the scrutiny of various national competition authorities (of which the NMa was one) was referred to the Commission because of the international status of the markets involved'. See Netherlands Competition Authority, NMa Annual Report 2005, 102.

48 Cengiz 'European Competition Network' (n 8) 18. As mentioned before, there do not seem to be serious problems with the way this allocation system works, and the NCAs seem quite happy to negotiate their jurisdiction informally. For example, the German Bundeskartellamt reported that in 2007-2008 one of the cases in which it started the investigation was transferred to the Commission's jurisdiction, one from the Commission's jurisdiction was transferred for it to investigate, and one was investigated in parallel. See Deutscher Bundestag, Bericht des Bundeskartellamtes über seine Tätigkeit in den Jahren 2007/2008 sowie über die Lage und Entwicklung auf seinem Aufgabengebiet' 47.

49 Oliver Budzinski \& Andt Christiansen, 'Competence Allocation in the EU Competition Policy System as an Interest-Driven Process' (2005) 25 Journal of Public Policy 313, 319; Francesco Maria Salerno, 'The Competition Law-ization of Enforcement: The Way Forward for Making the Energy Market Work?' (2008) EUI RSCAS Working Paper 2008/7, 5-6.
}

50 See n 32. 
An overview of the NCAs' reports confirms the Commission's claim that 'the actual intensity, scope and potential of cooperation within the ECN go beyond the legal obligations set out in Regulation 1/2003'. ${ }^{1}$ Some of it even goes beyond what the Directive foresees as an option (for example, the French NCA states that it also informs other NCAs and the Commission of "closed cases ${ }^{52}$ ). The way this actually works is well described in an annual report of the French NCA:

This co-ordination mainly takes two forms: firstly, at the start of proceedings, the authorities are required to inform one another about the cases pending before them, so that discussions can be held and, where appropriate, certain cases allocated between the authorities best placed to hear them, to ensure they are dealt with as efficiently as possible. Secondly, before the national authority concerned adopted a decision, the Commission oversees the proceedings to ensure the overall system is consistent. ${ }^{53}$

An important feature of the system is that the NCAs are using the possibilities for informal information exchange not only to co-ordinate their jurisdiction among themselves and tip each other off on potential wrongdoings, ${ }^{54}$ but also to run their proposed decisions by the Commission. There does not seem to be any obstacle for the Commission's input on the legal interpretation or economic reasoning overriding the initial position taken by the NCAs - in the name of 'consistency' of the system. Since this communication is not disclosed, for the sake of confidentiality, it is hard to know what exactly goes on. It should be expected that the Commission is not overly aggressive in trying to substitute its interpretation for that adopted by the NCA, but it can certainly steer it, case by case, towards the 'correct' application of Community rules.

The interplay between the NCAs themselves seems equally robust. Through their information sharing arrangements, they obtain detailed insight into each other's practice, which is deepened in informal discussions of cases. As described in a French report:

51 Commission Report (n 39) 20.

52 See $n$ 31, 37.

53 See $\mathrm{n} 31,35$.

54 For example, the Czech NCA informally informed the Irish competition authority on a possible breach of the Article 81 of the EC Treaty by a company seated in Ireland. In relation to a prohibited agreement of candidates to a public contract (bid rigging), operating in most EU countries, a party to which applied for the benefits of the leniency programme, the Office communicated with the European Commission and the Slovak, Hungarian and Polish competition authority'. Office for the Protection of Competition, Annual Report 2004, 35. 
This system of reciprocal information ... gives each national competition authority ... visibility over its counterparts' activities and, in practical terms, enables investigating case officers to share details of actual cases and pool their experience. ... Discussions about cases take place well before the authority concerned adopts a decision. They form a sort of interactive, dynamic system enabling the different authorities to pool their knowledge and expertise, so as to ensure that infringements are dealt with as effectively as possible. ${ }^{55}$

The emphasis on 'reciprocal' information exchange suggests that the NCAs have a strong interest in ensuring that all network participants co-operate more or less to the same extent. ${ }^{56}$ Those who try to evade this reciprocity might be condemned as free riders - benefiting from the information of others, asserting their jurisdiction vis-à-vis other NCAs or asking for assistance (eg in obtaining evidence), but holding out in some aspects of the information sharing mechanism. This peer pressure, if it indeed takes place, amounts to a strong guarantee of the effectiveness and 'depth' of the network. This, along with other available evidence, speaks in favour of the Commission's finding (in 2007) of a:

...continuation of the convergence process observed in the context of Regulation 1/2003. Over and above legal obligations arising from implementation of the Regulation, there is a trend towards greater approximation of national procedural laws and policies. ${ }^{57}$

Of course, even though all this takes place in the context of individual investigations, it is hardly plausible that this kind of co-ordination does not affect the NCAs' policy approach more generally. It is not realistic to maintain clear distinctions between policy-making and enforcement. The changing patterns, priorities and practical concerns in enforcement necessarily feed back into changes of policy. ${ }^{58}$ That said, the ECN also deals with competition policy in more direct ways.

\subsection{The ECN's policy planning channels}

The ECN is also a policy network, ${ }^{59}$ even though the Commission undoubtedly remains the most important policy actor in the network, burdened with no significant formal restraints. ${ }^{60}$ Unfortunately, it is hard to learn much about this aspect of the network, but for the reports of the agencies. However, it seems clear that the network is indeed taking an

\footnotetext{
55 See n 31, 36.

56 Cengiz, 'European Competition Network' (n 8) 12.

57 Commission Report (n 39) 21.

58 Wilks (n 9) 442.

59 But see Wilks (n 9) 440 for a view that the network is 'primarily' about enforcement.

60 Cengiz, 'European Competition Network' (n 8) 13.
} 
important role in policy formulation, which also links back to the harmonisation of national competition laws beyond what is required by modernisation $^{61}$ (see below in 3.4).

The image which emerges when studying the NCAs' reports is the following: network members regularly meet to discuss the future of Community competition policy, spurred mostly by proposals of the Commission which has by and large remained the agenda-setter in EC competition policy. So far, most of the significant policy initiatives discussed within the ECN have come from the Commission. Some of the examples are the Green Paper and White Paper on private enforcement and the guidelines on the application of art 82 (see below in 4.1), adopted after consultations with the NCAs and taking their responses into account.

Policy discussions within the ECN take place in three regular settings: plenary meetings, working groups and in the Advisory Committee, as well as through ad hoc channels.

Plenary meetings, which take place every three months on average, are devoted to the most general policy issues, to the review of the work of working groups, and are, most generally, used to 'adopt common policies'. ${ }^{62}$ Some of the topics covered at plenary meetings over the last few years have included the model leniency programme, draft Community legislation and the practicalities of co-operation within the network.

A number of working groups and subgroups are devoted to specific sectors, 'exchanging sectoral information and sharing experiences', as well as agreeing 'upon a common approach', 'if possible'. ${ }^{63}$ These groups are usually co-chaired by the Commission and one NCA. ${ }^{64}$ The working groups and subgroups cover areas as diverse as pharmaceuticals, professional and financial services, motor vehicles, the environment, telecommunications, banking, energy, media, food products, insurance, etc. Some of the groups are devoted to general competition enforcement issues, such as sanctions and the ne bis in idem principle, competition and consumer protection, co-operation issues, and information and communications'. ${ }^{65}$

Interestingly, some of the working groups discuss policy areas which sometimes fall outside the normal remit of competition policy. For example, the French and Dutch NCAs indicate that they worked on reports on the retail banking and payment card markets during 2005 and $2006 .{ }^{66}$

61 Cengiz, 'European Competition Network' (n 8) 19.

62 See n 31, 38.

63 See Netherlands Competition Authority, NMa Annual Report 2005, 100.

64 See n 31, 38.

65 For a fuller list, see Romanian Competition Council, Annual Report 2007, 53-55.

66 Netherlands Competition Authority, NMa Annual Report 2006, 30; see n 31, 38-39. 
In 2008, the Commission reported publishing its own study in this area - based on the NCAs' studies discussed within the ECN - which found, among other things, that 'markets remain fragmented along national lines' and that 'high degrees of variation of prices, profit margins and selling patterns ... were found to be indicative of persisting regulatory ... barriers to competition'. ${ }^{67}$ These are certainly legitimate concerns for the Commission, but regulatory barriers to competition are normally considered to be out of the scope of arts 81 and 82, and competition policy more broadly. They could perhaps be addressed under the EC Treaty provisions on free movement of services and/or capital, but that is far from the ambit of the ECN. Therefore, either the NCAs discuss issues of Community policy not related to the tasks they have been entrusted with, or the Commission uses the NCAs for research assistance in the formulation of Community policy.

The group with potentially the most profound effect on competition policy must be the working group of Chief Economists. This group assembles the top economists of the NCAs (many of which have recently introduced the position, modelled on that of the Commission and some of the more prominent NCAs) and of the Commission. It evolved from a seminar on the use of simulation models for mergers (an issue not legally under the remit of the ECN), organised by the Dutch NCA. ${ }^{68}$ The direct impetus for its formation came, tellingly, from the Commission:

Mr. Oliver Stehmann, a member of the Chief Economist's Office at the EU Commission, indicated that since the economic assessment is becoming increasingly important to the handling of cases involving anticompetitive practices and mergers, it appeared sensible for the competition authorities to come together to discuss the issue. ${ }^{69}$

It is hard to overstate the potential importance of this group. Economic analysis is an indispensable element of any antitrust investigation, especially under the now prevalent understandings of antitrust (see below in 3.1), and many of the officials working on such cases are economists by training. Agreeing on common principles of economic analysis is thus clearly not only a technical or academic issue, or even a gap-filler: it is tantamount to policy alignment.

The third form of policy co-operation is the Advisory Committee. The Network Notice defines it as the forum where experts from the various competition authorities discuss individual cases and general issues of Community competition law'. ${ }^{70}$ Typically, the advisory committee assesses the Commission's analysis of an individual case, perhaps suggesting

67 Commission Report (n 39) 10.

68 See Netherlands Competition Authority, Annual Report 2004 - NMa and DTe 49.

69 See n 3140.

70 Commission Notice (n 7) para 58. 
changes. The Commission has to consult the Committee and to take "the utmost account' of its opinion. However, the Advisory Committee is also consulted on more general policy issues:

...the Advisory Committee does not just give its opinion on the Commission's decisions. For example, in 2006, it gave its verdict on the Commission's new guidelines for calculating fines. ${ }^{71}$

Finally, there is also a number of ad hoc collaborative projects between the European Commission and the NCAs, such as a task force on the internal market for payment services (SEPA Task Force). There is also a system of staff exchange within ECA (European Competition Authorities), which is a less formal, 'think tank' network involving, apart from ECN members, also the Swiss and Norwegian NCAs.

Many of the NCAs, as well as the Commission itself, are also engaged in capacity building, where training sessions are organised for candidate and partner countries. Such a form of co-operation is the so-called Marchfeld forum, which sets up a parallel, softer system of co-operation between the Commission and ECN Members from Central and Eastern Europe, along with Croatia and Switzerland. ${ }^{72}$

\subsection{An example of soft harmonisation: The Model Leniency Pro- gramme}

One of the most prominent issues addressed within the ECN is the Leniency Programme. Leniency allows undertakings that are party to an illegal cartel to come forward and provide information, in exchange for immunity or lower fines. Before the ECN, leniency applications were a significant burden for undertakings, since they had to be separately filed in a number of Member States as well as with the Commission, under radically different rules (with regard to time limits, criteria, etc.), which increased the costs and complexity and jeopardised confidentiality. ${ }^{73}$ In cases which may involve several EU jurisdictions, undertakings did not have an incentive to report cartels unless they satisfied the leniency requirements of the strictest regime, thus creating an "undesirable "race-to-the-top"'.74

This is why the ECN was used to develop, in 2006, a Model Leniency Programme. ${ }^{75}$ This Model Programme has so far been quite successfully

\footnotetext{
71 See n 31, 41.

72 See the Marchfeld Declaration, Memorandum of Understanding (2008) < http://www. bwb.gv.at/NR/rdonlyres/A2914C5A-0462-4AAE-8A6D-3394E87540D9/35231/MemorandumofUnderstanding.pdf> accessed on 7 December 2010.

73 Wilks (n 6) 443.

74 Cengiz (n 46) 33.

75 The text of the programme is available at <http://ec.europa.eu/competition/ecn/model_leniency_en.pdf> accessed on 7 December 2010.
} 
and voluntarily used by most of the Member States to harmonise their leniency rules. Apart from harmonising national leniency provisions, the Model Programme simplified the application process by allowing undertakings to file a full application to the Commission and only a summary application to the NCAs, provided that the Commission is best placed to address that particular case. ${ }^{76}$

Today, all the Member States except two have leniency programmes, whereas in 2002, before Regulation 1/2003 and the formation of the ECN, only four did. The Model Leniency Programme is also the basis for the Commission's own Leniency Notice. As a result of this harmonisation, undertakings still have to prepare multiple filings, but can rely on a set of similar substantive criteria and procedural rules. While the convergence is an ongoing process and not everything is harmonised everywhere, the Programme has so far been a success.

The Leniency Programme has been described as the most remarkable achievement' of the ECN's policy fora. ${ }^{77}$ It is a good example of a substantive outcome that can be produced within the ECN, with political impetus coming from the Commission, but with most of the discussions taking place in an ECN expert group, with subsequent endorsement from the heads of all the ECN members. The ECN's Report on the Programme indicates that the work within the ECN has been a major catalyst in encouraging Member States and/or authorities to introduce and develop their leniency policies and in promoting convergence between them'. ${ }^{78}$

\section{The Europeanisation of competition}

As we have seen, the ECN has largely been a mobilising and unifying force in the context of both individual investigations and overall policy planning. There is, however, more to be said on the nature of competition regulation and how such a unifying effect has been achieved.

\subsection{Competition as a supranational policy}

Competition policy has been dubbed the 'best example of a supranationalized policy'79 in the EU, and the Commission's Directorate General for Competition (DG Comp) has even been called a transnational

\footnotetext{
76 See European Competition Network, 'ECN Model Leniency Programme: Report on Assessment of the State of Convergence' <ec.europa.eu/competition/ecn/model_leniency_programme.pdf> 1-2 accessed on 7 December 2010.

77 Cengiz, 'European Competition Network' (n 8) 19.

78 See n 76, 18-19.

79 Lee McGowan, 'Europeanization Unleashed and Rebounding: Assessing the Modernization of EU Cartel Policy' (2005) 12 Journal of European Public Policy 986, 988.
} 
agency'. ${ }^{80}$ Thanks to significant delegation from the Council, the Commission has so far regulated the competition field with an unprecedented degree of independence, both in policymaking and enforcement. This is the context within which the ECN should be understood.

As McGowan has argued, competition policy is a good illustration of neofunctionalism - the system created by the Member States forming 'a superimposed community of bureaucrats and lawyers whose decisions came to influence and determine policy approaches at both national and supranational levels'. Once created, 'the supranational competition regime started to develop its own dynamics and trajectory'. ${ }^{81}$ Over time, DG Comp has become more and more assertive in its approach, and the Commission has grown to be the undoubted focal point of European competition policy. This development was assisted by the business community which favoured a more centralised and predictable system of governance, also fitting into the neofunctionalist framework. ${ }^{82}$

Centralisation did not take place on the basis of majoritarian decision-making. The Commission itself has favoured regulation by soft law - guidelines and other non-binding measures. ${ }^{83}$ In turn, it has been assisted by the European Court of Justice and the General Court (formerly the Court of First Instance). For example, the ECJ imposed a duty on national courts to take non-binding Commission recommendations into account. ${ }^{84}$ Even if the ECJ is critical of the Commission's decisions in individual cases, judicial review can protect legal certainty and grant legitimacy to the Commission's role:

For one, we might expect a positive impact on the overall efficiency of European competition policy, which may find expression in a higher degree of legal certainty, in more coherence in the Commission's application of new modes of governance, and in a less disputed distribution of cases between national and supranational jurisdictions. ${ }^{85}$

How does the ECN fit into this story? 'Decentralisation' was itself initiated by the Commission because of its strained resources. ${ }^{86}$ In its latest report, the Commission seems satisfied at this level, claiming that decentralisation has enabled it to 'focus its resources on areas where it can

\footnotetext{
80 Wilks (n 9) 438.

81 Lee McGowan, Theorising European Integration: Revisiting Neo-Functionalism and Testing its Suitability for Explaining the Development of EC Competition Policy?' (2007) EioP Working Paper 2007-003, 25 May 2007, 4.1.

82 McGowan (n 81) 4.3; Budzinski \& Christiansen (n 49) 318.

83 Lehmkuhl (n 6) 148, 150.

84 Lehmkuhl (n 6) 151.

85 Lehmkuhl (n 6) 158.

86 Budzinski \& Christiansen (n 49) 320; Cengiz, 'European Competition Network' (n 8) 8-9.
} 
make a significant contribution to the enforcement of Articles [101] and [102 TFEU]' and be more proactive, eg by launching several large sector inquiries. ${ }^{87}$

However, as has been pointed out, this cannot be the only reason - not only does decentralisation incur costs of adjustment, but it only makes sense insofar as the NCAs themselves are able to take on the excess tasks of the Commission, which is questionable. ${ }^{88}$ Since it was acknowledged that the capabilities of the NCAs differ widely, it is not clear why the Commission would want decentralisation. Yet, it is perfectly clear that it was initiated by the Commission, and not because of majoritarian or political pressures. ${ }^{89}$

There are several plausible explanations for this, apart from the resource problem. The explanation most often put forward by the Commission itself is the creation of a 'common competition culture'. ${ }^{90}$ Because of the learning and allegiance shifts that take place in a community of nonpolitical experts (see below in 4.2), the actual result of decentralisation is the reinforcement of a common European competition policy.

The Commission's gradual assertion of regulatory power in competition policy since the inception of the EC has been described as 'agency escape'. ${ }^{91}$ Instead of following the mandate given to it by the principals (the Member States), the agent (Commission) has taken on an active role that can no longer be easily restrained by the principals. In a similar vein, the NCAs' role within the network may not be connected with any reassertion of power on the part of the Member States. Rather, it can be described as 'double delegation' ${ }^{\prime 2}$ - the NCAs' loyalties lie within the network just as much as within their own state. These points are addressed in more detail below.

\subsection{Drivers of convergence and centralisation}

A number of features of competition policy show that it is not conducive to independent, divergent development in a community of regulators such as the ECN. Rather, the desire for effective competition regulation in such a technical field has a strong centralising effect.

\footnotetext{
87 Commission (EC) Communication from the Commission to the European Parliament and the Council: Report on the Functioning of Regulation 1/2003 COM (2009) 206 final, 29 April 2009.

88 Budzinski \& Christiansen (n 49) 320.

89 Wilks (n 6) 436.

90 See $\mathrm{n} 9$.

91 Wilks, Lehmkuhl (n 6).

92 See Coen \& Thatcher (n 15) 50-51. According to them, "the weakness of the networks and the controls of their principals help to explain why double delegation was agreed to by both national and EU actors'.
} 
On the one hand, competition regulation is highly technical and requires skills in both legal and economic analysis. This naturally leads regulators to look to more experienced peers, rather than, for example, political actors within their own country. This is particularly the case with smaller NCAs. Who better to look to for guidance but the only agency with significant previous experience in enforcing EU competition rules the Commission? As a consequence, developments in European competition law are transplanted to the national level not only by virtue of legal hierarchy, but as a result of learning.

Moreover, an international outlook is a natural instinct for European competition lawyers, given that competition law in Europe was disseminated in the Member States' national laws, almost exclusively, only after its adoption in the Treaties (the most notable exception being German competition law ${ }^{93}$ ). Competition law has always primarily reflected a common EU policy. After half a century of such policy making, decentralised enforcement among agencies is unlikely to lead to drastically divergent views.

In practical terms, tight integration is also helped by the fact that the competition regulators' community is relatively small and, increasingly, well connected internationally. This has been described as an 'epistemic community', ${ }^{94}$ consisting of European and national agencies, academics, law firms and business entities. ${ }^{95}$ While this development has occurred gradually over the years, through the formation of communities of academics and practitioners, seminars, conferences, etc, in the European context it has also been actively pursued by the Commission. ${ }^{96}$ One of the explanations of the fact that the ECN is functioning well is precisely the 'success of competition specialists in the epistemic community in working with and through DG Comp to create a persuasive set of coordinative discourses'. 97

Direct contact with the regulated entities has been central in transforming DG Comp into Europe's foremost competition regulator. ${ }^{98}$ This contact is not lost with decentralisation, in that the Commission still conducts individual investigations; indeed, its powers to investigate and fine

\footnotetext{
93 For an account of those early days, see Giuliano Marenco, 'The Birth of Modern Competition Law in Europe' in Armin von Bogdandy, Petros C Mavroidis and Yves Mény (eds), European Integration and International Co-Ordination: Studies in Transnational Economic Law in Honour of Claus-Dieter Ehlermann (Kluwer Law International, The Hague, 2002) 279.

94 Stephen Wilks, 'Understanding Competition Policy Networks in Europe: A Political Science Perspective' (2002) EUI RSCAS Proceedings, 9. See also Cengiz (n 46) 2 footnote 5.

95 David J Gerber, 'The Evolution of a European Competition Law Network' (2002) EUI RSCAS Proceedings, 19.

96 Wilks (n 9) 451-453.

97 Wilks (n 9) 455.

98 Salerno (n 49) 2-3.
} 
were strengthened by Regulation 1/2003. Including the NCAs into this discourse, however, can only serve to grow and further develop a sense of community among experts, focusing the debate on common issues ${ }^{99}$ and aligning interests. ${ }^{100}$

The Global Competition Review now even publishes yearly 'rankings' of dozens of competition agencies ${ }^{101}$. The fact that such rankings are possible shows that competition policy in most developed countries, and certainly within the EU, presents problems that are so similar that a common frame of reference and assessment can be made. One of the most recent GCR surveys concluded that the playing field is becoming increasingly leveled, and there are ever fewer differences in the analytical skills of the leading authorities'. ${ }^{102}$

This is not to say that all differences have disappeared. Indeed, recent studies show that the NCAs of the EU can still be divided into several groups according to their institutional capacity, with the UK, French and German NCAs coming out on top. ${ }^{103}$ The fact that these differences are diminishing can be explained at least in part by the Commission's influence. Thus, Lehmkuhl has argued that institutional disparities lead to the Commission's guidelines, notices, etc, acquiring an almost binding character in practice. ${ }^{104}$

Interestingly, as conveyed by Wilks:

The survey indicates levels of prestige, both administrative and doctrinal. It therefore reflects ideas in good currency and it is significant that the German Bundeskartellamt (BKA) has fallen in prestige. The GCR remarks that the 'Federal Cartel Office was once perhaps the world's most influential antitrust authority, [but] now finds itself adrift from the mainstream, clinging stubbornly to the per se rule of anti-competitive behavior'. ${ }^{105}$

This shows that the emergence of an 'epistemic community' is more than just an important unifying force in European competition law. Over the years, it has led to harmonisation of national competition laws beyond

\footnotetext{
99 Fox (n 23) 144.

${ }^{100}$ Gerber (n 95) 18.

${ }^{101}$ See Global Competition Review <http://www.globalcompetitionreview.com/surveys/ survey/376/Rating-Enforcement/ > accessed on 7 December 2010. See also Wilks (n 9) 443. The US (FTC) and UK (Competition Commission) agencies and the European Commission usually end up at the top. The criteria for assessment are quite detailed: for example, "the use of IT to speed evidence-sifting, handling a "mass leniency" application by an entire industry, being "tough" on dawn raids' etc.

102 The Netherlands Competition Authority, NMa Annual Report 2007, 45.

${ }^{103}$ Wilks (n 9) 447.

${ }^{104}$ Lehmkuhl (n 6) 151.

105 Wilks (n 9) 444.
} 
what was required by Community law (in fact, even in the separate spheres of purely national competition laws, see below in 3.4) and far beyond what could have been achieved by top-down pressure from the Commission and the European Court of Justice. ${ }^{106}$ Today, it is also increasingly leading to convergence in what is considered solid economic and legal thinking.

\subsection{Depoliticisation and regulatory independence}

More recently, the Commission has been moving strongly in the direction of a depoliticised competition policy, independent of other regulatory concerns. In the earlier history of the European Community, competition rules were seen as only one part of the broader political goal of European integration, specifically as a necessary complement to free movement rules, which protect the circulation of economic factors from regulatory interference of the Member States. ${ }^{107}$ The idea was to prevent private restraints, such as exclusionary conduct or restrictive agreements among undertakings, from taking the place of governmental barriers.

Today, however, the tendency is to view competition rules as being independent. Competition policy is no longer merely about integration. ${ }^{108}$ It is concerned more directly with protecting market efficiency: preventing restraints which cannot themselves be justified by procompetitive (and only procompetitive) considerations. ${ }^{109}$ This approach is at least somewhat influenced by modern US antitrust law: protecting 'competition, not competitors' by preventing loss to consumer welfare. There is resistance, for example, against using non-efficiency based justifications (such as, for example, environmental protection) for anticompetitive conduct, or against interfering with conduct which leads to discernible efficiencies, such as lower prices.

There is no need here to assess the value of that approach. Its proponents describe earlier EC practice as overly formalistic and legalistic; its detractors, meanwhile, criticise the new approach as too narrow and influenced by 'Chicago-school' thinking. What is relevant to this discussion is that the Commission is solidifying its view of competition policy through the ECN.

\footnotetext{
${ }^{106}$ Frans van Waarden \& Michaela Drahos, 'Courts and (Epistemic) Communities in the Convergence of Competition Policies' (2002) 9 Journal of European Public Policy 913, 932933.

${ }^{107}$ Heike Schweitzer, The History, Interpretation and Underlying Principles of Section 2 Sherman Act and Article 82 EC' (2007) EUI RSCAS Proceedings 40.

108 Cengiz (n 46) 28.

109 Wilks (n 6) 440.
} 
For example, the Commission has used the ECN to pursue innovations such as private enforcement (see below in 4.1). Quasi-legislative instruments such as the Commission's guidelines on exclusionary conduct, adopted after consultations within the ECN, are widely seen as furthering a new, more economic approach. The adoption of formal policy co-ordination mechanisms within the ECN, such as the Working Group of Chief Economists, shows a tendency towards harmonising the economic reasoning underlying antitrust enforcement.

Closely linked to this is the strong emphasis on the independence of the NCAs. By avoiding political pressures and focusing on a technical discourse among experts, the agencies are more suited to rallying around unified assumptions and objectives, especially if their independence ever comes into question. This certainly repudiates the fear that national political influence will lead to policy divergence among the Commission and the NCAs:

As regards sectoral agency solidarity, almost without exception the NCAs are depoliticized agencies with delegated powers who are fiercely jealous of their independence. Their legal foundations, their self-esteem and their operational credibility all rely upon maintaining independence from politicians, government ministries and powerful indigenous business interests. In this setting external support from sister agencies and from DG Comp is a powerful weapon of defense. ${ }^{110}$

Even before the ascent of the ECN, national competition authorities were seen to be growing in independence and professionalism, which explains why the role of national allegiances in the ECN is not as significant as might be expected. ${ }^{11}$

\subsection{Feedback: European and national competition law}

Even though the NCAs are to a significant extent independent of their national polities (at least to the extent explained by 'double delegation'), the policies discussed and agreed within the ECN, primarily meant to govern only at the level of EU law, are increasingly adopted as binding national law in their respective countries. National competition law mirrors EU rules, even though there is no legal obligation to do so.

\footnotetext{
${ }^{110}$ Wilks (n 9) 450. Budzinski and Christiansen (n 49) 317 approach the problem differently: 'Hence, the large Member States typically show a high interest in preserving their competences, which makes them the natural opponents of centralisation in competition policy matters. The same applies to the NCAs, which is why we treat them together with their respective governments.'

${ }^{111}$ Støle (n 21) 16.
} 
The division of competences in competition law thus becomes, in itself, a factor contributing to regulatory convergence. Even though competition law falls within the exclusive competences of the EU, there are still 27 national competition laws, enforced by the respective NCAs. This is because EU competition rules apply only to the extent that trade between Member States is affected. Falling below that threshold is any number of cases to which only national rules apply. As long as those national rules do not jeopardise the exercise of EU competences in some way, they can be different from European rules, even in ostensibly similar situations.

Predictably, however, there is no clear line between practices that do or do not affect cross-border trade. Interpretations of this concept by the European Court of Justice have been largely permissive, ie in favour of the applicability of EU law. ${ }^{112}$

This lack of a clear distinction has led to the development of bodies of rules which are largely convergent. National competition laws - at least their basic principles and the broad features of the enforcement powers, if not the entirety of the procedural rules - are being modelled to mirror European rules, a process which many NCAs support or even advocate. This can be explained by the obvious difficulty in exercising two parallel but completely different jurisdictions. Since it is not entirely clear if EU law or national law will apply in a given set of cases, the enforcement of very different bodies of laws would probably be an administrative nightmare. Consequently, national competition laws have been amended to approximate EU rules, even on matters of procedure. For example, the Dutch legislature has abolished the national system of notification and exemption after this was done at the EU level by Regulation 1/2003. ${ }^{113}$

Moreover, there is evidence that the 'pull' of the European approach has caused national courts and NCAs to change their views on some prominent competition policy issues, whether in the context of EU or national law. ${ }^{114}$

\footnotetext{
112 Wilks (n 5) 445.

113 The Netherlands Competition Authority, Annual Report 2004 - NMa and DTe, 22.

114 Thus, the Dutch NCA reports that:

- 'following European case law, there is a clearly discernible trend in national case law towards a greater emphasis by the courts on the economic effects of prohibited practices' (2006 Report);

- 'the NMa's merger control has been brought further in line with European competition law; ... when assessing mergers, the focus is now more on the question of whether competition is being restricted by a merger and less on whether it is being caused by an economically dominant position; ... from now on, besides mergers and acquisitions, cooperative joint ventures will also be inspected' (2007 Report);

- '...by reducing fines the NMa aims to contribute to the enforcement of competition legislation by means of the injured party's demand for compensation as directed towards the undertakings which have acted in breach of competition law; ... this so-called civil enforcement is furthered by the European Commission as part of the modernisation of communal competition law' (2005 Report).
} 
There are at least two conclusions to be drawn at this point. First, the intellectual influence of European competition policy and the administrative convenience of applying similar rules to similar situations lead to the convergence of national and European rules far beyond what is required by the supremacy of European law. Second, even though the NCAs show a high degree of independence from their national governments, the policies agreed within the ECN are adopted, by national legislatures, into national law. This implies that the NCAs are able, at least to some extent, to influence their own governments and/or legislatures.

\section{A caveat and a challenge}

\subsection{The caveat: possible pressures for divergence}

Even if the Commission's voice is so far dominant within the ECN, some NCAs still take clearly opposite policy positions. An example is the opposition of the German NCA to two of the Commission's most significant policy documents in the field of competition policy in recent years: its White Paper on private enforcement ${ }^{115}$ and its guidance on the enforcement of art $82 \mathrm{EC}$ (exclusionary conduct). ${ }^{116}$

The private enforcement guidelines are influenced by American law, with the goal of making it easier for individuals to obtain damages from firms that breach competition rules. With its Green Paper and, more recently, White Paper, the Commission is opening the debate for a possible legislative solution, requiring certain minimum procedural standards from the Member States.

This approach has met strong resistance from the German Bundeskartellamt, arguing that there is no need for legislation at the European level at all and that such an approach would jeopardise coherence in the Member States' systems of tort law. There have also been more specific objections to the proposed system of anonymous class actions and discovery processing. ${ }^{117}$

Similarly, the Bundeskartellamt opposes the introduction of market efficiency defences for art 82 exclusionary conduct, relying on the fact that they are only provided for in the text of art $81 \mathrm{EC} .{ }^{118}$ The Conseil de

\footnotetext{
${ }_{115}$ Commission (EC) White Paper on damages actions for breach of the EC antitrust rules, COM (2008) 165 final, 2 April 2008.

${ }^{116}$ Commission (EC) Guidance on the Commission's enforcement priorities in applying Article 82 of the EC Treaty to abusive exclusionary conduct by dominant undertakings $\mathrm{C}$ (2009) 864 final, 9 February 2009.

117 See Bundeskartellamt, Our Activities in 2005 and 200616.

${ }^{118}$ Bundeskartellamt (n 117) 14-15.
} 
la Concurrence, however, has taken the opposite position. ${ }^{119}$ Both NCAs have argued that the likely market effect should suffice in proving breaches, an approach which does not seem to have been contradicted by the Commission's proposals.

These examples of opposition show that, even though the ECN so far has had a largely unifying effect on the discourse of competition policy, things could change. But some of the leading NCAs which have so far been vocal in their objections might find themselves overwhelmed by many other NCAs whose experience in implementing competition law has primarily been guided by the Commission. For example, the Member States that joined the Union in 2004, along with likely future members, have largely implemented competition rules in order to comply with accession requirements - a discourse that has been completely dominated by the Commission.

It is hard to predict what this means for the future of competition regulation in the EU. One could speculate that, once the NCAs have gained more experience, there could be more pressure towards changing the Community's policy. The ECN could then be used as a more even-footed forum for mutual learning and for the reformulation of policies. So far, however, the system seems to be having a unifying effect and is being largely guided by the Commission.

\subsection{The challenge: transparency and accountability}

One challenge which will probably have to be addressed in the near future is the worrying lack of transparency and legal accountability of the ECN's work, both in the enforcement sphere and in the policy planning sphere.

The increased use of soft law, as well as the informal nature of decisions within the network, when dealing with specific cases, is problematic from the aspect of the judicial protection of the affected undertakings: 'it is not impossible for example to demonstrate that a decision of the Commission to refer a case to a national competition authority is liable to affect the rights of parties'. ${ }^{120}$

Thus, even though the network makes enforcement more efficient by subjecting cases to more flexible discussion among the NCAs, there are inevitably serious due process issues. Is it really inconceivable that the informal, confidential back-and-forth process within the network can adversely affect the rights of undertakings, especially their right to be he-

\footnotetext{
119 See Conseil de la Concurrence, 2005 Activity Report 59-61.

${ }^{120}$ Laura Parret, 'Judicial Protection after Modernisation of Competition Law' (2005) 32 Legal Issues of European Integration 339, 359.
} 
ard? To mention one striking example, the parties cannot access Commission communications reported back to the NCAs after they submit their envisaged decisions. ${ }^{121}$ So far, however, the informal communication within the ECN continues to be shrouded in mystery and is, as it seems, not subject to review before the European courts. ${ }^{122}$

Concerns regarding transparency in the policy-making stage are perhaps not as acute, but could also become a systematic problem, especially as the discussion begins to affect increasingly wide matters of policy. At the most basic level, the contrast between the amount of information available from DG Comp, and even from most of the NCAs, and what can be found on the ECN's own website, is stark. One has to delve into the NCAs' annual reports to find any mention, for example, of the ECN's working groups, let alone to learn what is being discussed within them and what the positions of individual NCAs are. It seems that all the participants in the network prefer informal, non-public modes of communication. ${ }^{123}$

\section{Conclusion}

Through regulatory decentralisation, the ECN has in fact achieved convergence, both in the sphere of enforcement and in the sphere of policy. The NCAs have been loyal and active participants in the network, complying with the Regulation and the Notice, following the rules on cooperation, the provision of information and allocation of competences. There have been no reported cases of jurisdictional conflicts, and the Commission has so far not used its power of removal. This paper has attempted to show that the modernised system has indeed led to greater convergence, and to identify some reasons for such a development.

The ECN's unifying impact can be seen from most of the available reports, both of the Commission and of the NCAs, as well as from the statistics showing that the burden of enforcement has indeed largely shifted to the NCAs. ${ }^{124}$ The NCAs report participating actively in the ECN's policy fora, as well as engaging their counterparts in a flexible and effective system of case management and resolution.

\footnotetext{
${ }^{121}$ Cengiz, 'European Competition Network' (n 8) 18.

122 See Cengiz ( $\mathrm{n}$ 46) 24-25, and the case law cited in $\mathrm{n} 96$.

${ }^{123}$ Cengiz (n 46) 24-25.

${ }^{124}$ As an illustrative example, in 2004 the Network was notified of 101 Commission investigations and 211 NCA investigations. Between 1 January 2010 and 31 October 2010, the figures were only 11 for the Commission and 123 for NCAs. See <http://ec.europa.eu/ competition/ecn/statistics.html> accessed on 7 December 2010.
} 
The reasons can be traced back to the technical, expert-driven nature of competition law. The assertion of the Commission as the centre of European competition policy was created within an epistemic community of regulators, judges, scholars and practitioners. The Commission has continued to act as the agenda-setter and has been successful in pushing through most of its suggested reforms. This has fed back into reforms of national competition laws going beyond the requirements of the supremacy of EC law, mirroring European developments in the national setting. The NCAs seem to be playing out their allegiance to the 'epistemic community' rather than being dominated by the political arena of their own state.

Much of this, however, can change as more of the NCAs develop their own particular approaches and become more assertive within the ECN. This is the risk posed by decentralisation. ${ }^{125}$ In the short run, peer pressure can dampen the impact of dissent; in the long run, that may no longer be the case. This scenario would provide a real test for a fullfledged regulatory network between equals. We will have to wait until then to see if the 'dispersal of decision-making responsibilities' can truly 'help realize one of the great benefits of diversity in enforcement and adjudication - surfacing hard issues for debate and creating dialogue as to what the law is and should be'. ${ }^{126}$

${ }^{125}$ Wilks (n 6) 447.

${ }^{126}$ Fox (n 23) 143. 